\title{
ANALISIS PENGARUH PERTUMBUHAN EKONOMI TERHADAP TINGKAT KEMISKINAN DI SUMATERA UTARA
}

\author{
Nadia Ika Purnama \\ Dosen Fakultas Ekonomi dan Bisnis Universitas Muhammadiyah Sumatera Utara \\ email : nadiaika95@gmail.com
}

\begin{abstract}
ABSTRAK
Kemiskinan merupakan salah satu masalah dalam perekonomian yang kompleks dan multidimensional. Oleh karenanya perlu dicari solusi untuk mengatasi atau paling tidak mengurangi tingkat kemiskinan. Penelitian ini bertujuan untuk menganalisis pengaruh tingkat pertumbuhan ekonomi terhadap tingkat kemiskinan di propinsi Sumatera Utara.

Penulis menggunakan instrumen penelitian kepustakaan, studi dokumentasi, browsing internet, dimana data yang diambil merupakan data skunder dari instansi terkait terutama Badan Pusat Statistik Sumatera Utara, serta dalam menganalisis data menggunakan teknik analisis regresi linier sederhana.

Hasil pengolahan data didapat pertumbuhan ekonomi berpengaruh negatif dan signifikan terhadap tingkat kemiskinan di propinsi Sumatera Utara.
\end{abstract}

\section{Kata Kunci : kemiskinan, pertumbuhan ekonomi}

\section{A. PENDAHULUAN}

Kemiskinan merupakan fenomena yang terjadi hampir di semua negara sedang berkembang. Kemiskinan muncul karena ketidakmampuan sebagian masyarakat untuk menyelenggarakan hidupnya sampai suatu taraf yang dianggap manusiawi. Kondisi ini menyebabkan menurunnya kualitas sumber daya manusia sehingga produktifitas dan pendapatan yang diperolehnya rendah.

Masalah kemiskinan merupakan salah satu masalah utama dalam pembangunan ekonomi. Pembangunan ekonomi pada hakekatnya bertujuan untuk meningkatkan kesejahteraan masyarakat, meningkatkan pendapatan serta pertumbuhan ekonomi di semua sektor pembangunan, pemerataan pembangunan yang optimal, perluasan tenaga kerja dan peningkatan taraf hidup masyarakat. Dalam mencapai tujuan pembangunan secara menyeluruh diperlukan adanya pertumbuhan ekonomi yang meningkat dan distribusi mendapatan yang merata.

Pemerintah Indonesia menyadari bahwa pembangunan nasional adalah salah satu upaya untuk menjadi tujuan masyarakat adil da makmur. Sejalan dengan tujuan tersebut, berbagai kegiatan pembangunan telah diarahkan kepada pembangunan daerah khususnya daerah yang relative mempunyai tingkat kemiskinan yang terus naik dari tahun ke tahunn. Pembangunan daerah dilakukan secara terpadu dan berkesinambungan sesuai prioritas dan kebutuhan masing-masing daerah dengan akar dan sasaran pembangunan nasional yang telah ditetapkan melalui pembangunan jangka panjang dan jangka pendek. Oleh karena itu, salah satu indikator utama keberhasilan pembangunan nasional adalah laju penurunan jumlah penduduk miskin. Efektifitas dalam enurunnkan jumlah penduduk miskin merupakan pertumbuhan utama dalam memilih strategi pembangunan. Hal ini berarti salah satu criteria utama pemilihan sector titik berat atau sector andaahn pembangunan nasional adalah efektifitas dalam penurunan jumlah penduduk miskin (Ravi Dwi Wijayanto, 2010). 
Pemerintah baik pusat maupun daerah telah berupaya dalam melaksanakan berbagai kebijakan dan program-program penanggulangan kemiskinan namun masih jauh dari induk permasalahan. Kebijakan dan program yang dilaksnakan belum menampakkan hasil yang optimal. Masih terjadi kesenjangan antara rencana dengan pencapaian tujuan karena kebijakan dan program penanggulangan kemiskinan lebih berorientasi pada program sektoral. Oleh karena itu diperlukan suatu strategi penanggulangan kemiskinan yang terpadu, terintegrasi dan sinergis sehingga dapat menyelesaikan masalah secara tuntas.

Dimensi kemiskinan dapat berbentuk dari aspek ekonomi, aspek SDM, fisik/infrastruktur, masalah sosial dan keluarga/rumah tangga. Perlu diperhatikan bahwa yang dibutuhkan masyarakat miskin tidak hanya bantuan modal/materi, tetapi juga suatu kondisi yang kondusif yang memungkinkan mereka untuk membentuk jaringan sosial dan ekonomi di antara mereka sendiri. Pemerintah daerah dan Lembaga Swadaya Masyarakat (LSM) seringkali merupakan lembaga yang terbaik untuk menyediakan lingkungan seperti tersebut (Sumedi dan Supadi, 2004).

Tabel 1

Tingkat Kemiskinan di Sumatera Utara

Tahun 1996-2015

\begin{tabular}{|c|c|c|}
\hline No & Tahun & $\begin{array}{c}\text { Persentase penduduk Miskin } \\
(\text { Y) }\end{array}$ \\
\hline 1 & 1996 & 10.92 \\
\hline 2 & 1997 & 11.27 \\
\hline 3 & 1998 & 30.77 \\
\hline 4 & 1999 & 16.74 \\
\hline 5 & 2000 & 15.84 \\
\hline 6 & 2001 & 15.75 \\
\hline 7 & 2002 & 15.84 \\
\hline 8 & 2003 & 15.89 \\
\hline 9 & 2004 & 14.93 \\
\hline 10 & 2005 & 14.68 \\
\hline 11 & 2006 & 15.66 \\
\hline 12 & 2007 & 13.9 \\
\hline 13 & 2008 & 12.55 \\
\hline 14 & 2009 & 11.51 \\
\hline 15 & 2010 & 11.36 \\
\hline 16 & 2011 & 10.83 \\
\hline 17 & 2012 & 10.41 \\
\hline 18 & 2013 & 10.39 \\
\hline 19 & 2014 & 9.85 \\
\hline 20 & 2015 & 10.53 \\
\hline
\end{tabular}

Sumber : BPS, 2016.

Permasalahan strategi di pemerintahan propinsi Sumatera Utara tidak jauh berbeda dengan di pemerintahan pusat, yakni masih tingginya angka kemiskinan jika dibandingkan dengan propinsi lain di Indonesia seperti propinsi DKI. Jakarta, 
Kalimantan Selatan, Bali, Kalimantan Tengah dan Kepualauan Bangka Belitung yang cukup rendah bila dibandingkan dengan propinsi lain di Indonesia yakni berkisar antara 3-7 persen.

Keberhasilan propinsi Sumatera Utara dalam menanggulangi kemiskinan belum sepenuhnya berhasil. Ini terlihat dari tingkat kemiskinan yang masih relatif tinggi yaitu angka diatas 10 persen. Rata-rata tingkat kemiskinan Sumatera Utara periode 19962015 masih relatif tinggi yaitu di atas 10 persen. Hanya tahun 2014 persentase penduduk miskin dibawah 10 persen yaitu sebesar 9,85\%. Dan di tahun 2015 tingkat kemiskinan di Sumatera Utara meningkat kembali menjadi 10,53\%. Oleh karena itu, kemiskinan menjadi tanggung jawab bersama, terutama pemerintah sebagai penyangga proses perbaikan kehidupan masyarakat dalam sebuah pemerintahan, untuk segera mencari jalan keluar dengan merumuskan langkah-langkah yng sistematis dan strategis sebagai upaya pengentasan kemiskinan.

Pertumbuhan ekonomi merupakan tema sentral dalam kehidupan ekonomi semua Negara di dunai dewasa ini. Pemerintah di Negara manapun dapat segera jatuh atau bangun berdsarkan tinggi rendahnya tingkat pertumbuhan ekonomi yang dicapainya dalam catatan statistik nasional. Berhasil tidaknya program-program di negara-negara dunia ketiga sering dinilai berdasarkan tinggi rendahnya tingkat output dan pendapatan nasional (Todaro, 2000).

Hasil studi empiris yang dilakukan oleh Mills dan Pernia (1993) dengan metode analisis lintas negara menunjukkan bahwa kemiskinan di suatu negara akan semakin rendah jika pertumbuhan ekonominya pada tahun-tahun sebelumnya tinggi dan semakin tinggi laju pertumbuhan PDB semakin cepat turunnya tingkat kemiskinan (Tambunan, 2011).

Tabel 2

Pertumbuhan Ekonomi Sumatera Utara

Tahun 1996-2015

\begin{tabular}{|c|c|c|}
\hline No & Tahun & $\begin{array}{c}\text { Pertumbuhan Ekonomi } \\
(\mathrm{X})\end{array}$ \\
\hline 1 & 1996 & 9.01 \\
\hline 2 & 1997 & 5.7 \\
\hline 3 & 1998 & -10.9 \\
\hline 4 & 1999 & 2.59 \\
\hline 5 & 2000 & 4.83 \\
\hline 6 & 2001 & 3.72 \\
\hline 7 & 2002 & 4.07 \\
\hline 8 & 2003 & 4.48 \\
\hline 9 & 2004 & 5.74 \\
\hline 10 & 2005 & 5.48 \\
\hline 11 & 2006 & 6.2 \\
\hline 12 & 2007 & 6.9 \\
\hline 13 & 2008 & 6.39 \\
\hline 14 & 2009 & 5.07 \\
\hline 15 & 2010 & 6.42 \\
\hline 16 & 2011 & 6.66 \\
\hline 17 & 2012 & 6.45 \\
\hline
\end{tabular}




\begin{tabular}{|c|c|c|}
\hline 18 & 2013 & 6.07 \\
\hline 19 & 2014 & 5.23 \\
\hline 20 & 2015 & 5.1 \\
\hline
\end{tabular}

Sumber : BPS, 2016.

Pertumbuhan ekonomi suatu daerah dapat diukur dengan melihat PDRB dan laju pertumbuhannya atas harga konstan. Rata-rata pertumbuhan ekonomi Sumatera Utara pada tahun 1996-2015 yaitu sebesar 4,76\%. Tahun 1996-2009 pertumbuhan ekonomi Sumatera Utara cenderung menurun dan berfluktuatif. Di tahun 1996-1997 mengalami penurunan sebesar 3,31\%. Namun, pada tahun 1997-2009 pertumbuhan ekonomi Sumatera Utara masih dibawah 9\% (lebih rendah dari tahun 1996). Khusus di tahun 1998 pertumbuhan ekonomi Sumatera Utara minus yatu sebesar -10,90\% dikarenakan dampak dari krisis moneter yang terjadi di Indonesia. Selama periode 2001-2008, perekonomian Sumatera Utara menunjukkan adanya peningkatan dari tahun ke tahun yaitu berkisar 3,72\% sampai 6,39\%. Tahun 2009 pertumbuhan ekonomi Sumatera Utara menurun dikisaran 5,07\% tetapi tahun 2010 sampai tahun 2013 mengalami peningkatan kembali dikisaran 6\%. Dan di tahun 2014 dan 2015 pertumbuhan ekonomi menurunkembali dikisaran 5\%. Namun pertumbuhan ekonomi Sumatera Utara tidak selalu diiringi dengan penurunan kemiskinan yang signifikan di propinsi Sumatera Utara. Bahka ketika indikator perekonomian Sumatera Utara naik di tahun 2001-2003 tingkat kemiskian juga naik mencapai 15,89\%.

Faktor yang mempengaruhi kemiskinan adalah pertumbuhan ekonomi. Pertumbuhan ekonomi yang tinggi dan disertai hasil pertumbuhan ke seluruh sector usaha sangat dibutuhkan dalam upaya menurunnkan tingkat kemiskinan. Maka untuk mempercepat penurunan tingkat kemiskinan, pertumbuhan ekonomi harus ditingkatkan. Dan diharapkan sektor pertanian, sektor industri pengolahan dan sektor jasa yang meningkat dapat menurunkan tingkat kemiskinan di propinsi Sumatera Utara.

\section{B. LANDASAN TEORITIS Kemiskinan}

Kemiskinan adalah suatu situasi atau kondisi yang dialami seseorang atau kelompok orang yang tidak mampu menyelenggarakan hidupnya sampai suatu taraf yang dianggap manusiawi (Sumedi dan Supadi, 2004). Sedangkan menurut Bachtiar Chamsyah (2006) menyatakann bahwa emiskinan merupakan suatu kondisi hidup yang merujuk pada keadaan kekurangan atau kesulitan dalam memenuhi kebutuhan hidup. Seseorang dikatakan miskin, apabila mengalami kesulitan dalam memenuhi kebutuhan pokoknya.

Dari definisi diatas diperoleh pengertian bahwa kemiskinan merupakan kondisi hidup seseorang yang merujuk pada keadaan kekurangan dalam memenuhi kebutuhan hidup pokkoknya dan tidak dapat menikmati kehidupannya dalam hal kesehatan, ibadah menurut agamanya, pendidikan, pekerjaan, pendapatan yang tinggi dan standar hidup yang layak.

Negara terbelakang atau negara sedang berkembang umumnya terjerat ke dalam lingkaran kemiskinan. Menurut Nurkse lingkaran kemiskinan mengandung arti deretan melingkar kekuatan-kekuatan yang satu sama lain beraksi dan bereaksi sedemikian rupa sehingga menempatkan suatu negara miskin tetap berada dalam keadaan melarat. Si miskin, misalnya selalu kurang makan, karena kurang makan, kesehatannya menjadi buruk; karena fisiknya lemah kapasitas kerjanya rendah; karena kapasitas kerjanya 
rendah penghasilannya pun rendah dan itu berarti ia miskin, akhirnya ia tidak akan mempunyai cukup makan dan seterusnya. Bila keadaan seperti ini dikaitkan dengan negara secara keseluruhan dapat dikemas ke dalam dalil kuno : "Suatu negara miskin karena ia miskin (Jhingan,M.L, 2010).

\section{Ukuran Kemiskinan}

Menurut BPS, tingkat kemiskinan didasarkan pada jumlah rupiah konsumsi berupa makanan yaitu 2100 per orang per hari (dari 52 jenis komoditi yang dianggap mewakili pola konsumsi penduduk yang berada di lapisan bawah) dan konsumsi non makanan (dari 45 jenis komoditi makanan sesuai kesepakatan nasional dan tidak dibedakan antara wilayah pedesaan dan perkotaan). Patokan kecukupan 2100 kalori ini berlaku untuk semua umur, jenis kelamin dan perkiraan tingkat kegiatan fisik, berat badan, serta perkiraan status fisiologis penduduk, ukuran ini sering disebut dengan garis kemiskinana. Penduduk yang memiliki pendapatan dibawah garis kemiskinan dikatakan dalam kondisi miskin.

Secara sederhana dan umumnya ukuran kemiskinan dapat dibedakan menjadi tiga yaitu :

1. Kemiskinan Absolut

Seseorang termasuk golongan miskin absolut apabila hasil pendapatannya berada dibawah garis kemiskinan dan tidak cukup untuk menentukan kebutuhan dasar hidupnya. Konsep ini dimaksudkan untuk menentukan tingkat pendapatan minimum yang cukup untuk memenuhi kebutuhan fisik terhadap makanan, pakaian, dan perumahan untuk menjamin kelangsungan hidup.

2. Kemiskinan Relatif

Seseorang termasuk golongan miskin relatif apabila telah dapat memenuhi kebutuhan dasar hidupnya, tetapi masih jauh lebih rendah dibanndingkan dengan keadaan masyarakat sekitarnya. Berdasarkan konsep ini, kemiskinan akan mengalami perubahan bila tingkat hidup masyarakat berubah sehingga konsep kemiskinan ini bersifat dinamis atau akan selalu ada.

3. Kemiskinan Kultural

Seseorang termasuk golongan miskin kultural apabila sikap orang atau sekelompok masyarakat tersebut tidak mau berusaha memperbaiki tingkat kehidupannya sekalipun ada usaha dari pihak lain yang membantunya atau dengan kata lain seseorang tersebut miskin karena sikapnya sendiri yaitu pemalas dan tidak mau memperbaiki kondisinya.

Semua ukuran kemiskinan dipertimbangkan berdasarkan pada norma pilihan dimana norma tersebut sangat penting terutama dalam hal pengukuran didasarkan konsumsi (consumption based poverty line). Oleh sebab itu, garis kemiskinan yang didasarkan pada konsumsi terdiri dari dua elemen (Ravi Dwi Wijayanto, 2010) yaitu :

a. Pengeluaran yang diperlukan untuk member standar minimum dan kebutuhan mendasar lainnya.

b. Jumlah kebutuhan yang sangat bervariasi yang mencerminkan biaya partisipasi dalam kehidupan sehari-hari.

Menurut Foster, dkk (Tambunan, 2001) terdapat tiga indikator untuk mengukur kemiskinan yang sering digunakan di dalam banyak studi empiris. Pertama, the incidence of poverty : persentase dari populasi yang hidup di dalam keluarga dengan pengeluaran konsumsi per kapita di bawah garis kemiskinan. Indeksnya sering disebut rasio $\mathrm{H}$. Kedua, the depth of poverty yang menggambarkan dalamnya kemiskinan di 
suatu wilayah yang diukur dengan indeks jarak kemiskinan (IJK) atau dikenal dengan sebutan poverty gap index. Indeks ini mengestimasi jarak/perbedaan rata-rata pendapatan orang miskin dari garis kemiskinan sebagai suatu proporsi dari garis tersebut. Ketiga, the serverity of poverty yang diukur dengan indeks keparahan kemiskinan (IKK). Indeks ini pada prinsipnya sama seperti IJK. Namun, selain mengukur jarak yang memisahkan orang miskin dari garis kemiskinan, IKK juga mengukur ketimpangan di antara penduduk miskin atau penyebaran pengeluaran di antara penduduk miskin. Indeks ini yang juga disebut Distributionally Sensitive Index yang dapat juga digunakan untuk mengetahui intensitas kemiskinan.

\section{Pertumbuhan Ekonomi}

Menurut Sadono Sukirno (2006) pertumbuhan ekonomi dapat didefinisikan sebagai perkembangan kegiatan dalam perekonomian yang menyebabkan barang dan jasa yang diproduksikan dalam masyarakat bertambah.

Tingkat pertumbuhan ekonomi dalam suatu tahun tertentu (tahun $t$ ) dapat ditentukan dengan menggunakan formula sebagai berikut :

Dimana :

$$
\mathrm{PE}=\frac{P \quad-P \quad-1}{P \quad B t-1} \times 100 \%
$$

PE $\quad=$ tingkat pertumbuhan ekonomi $(\%)$

$\mathrm{PDRB}_{\mathrm{t}} \quad=$ PDRB pada tahun $\mathrm{t}$

$\mathrm{PDRB}_{\mathrm{t}-1} \quad=$ PDRB pada tahun sebelumnya

\section{Faktor-faktor Yang Menentukan Pertumbuhan Ekonomi}

Menurut Todaro (1997) ada tiga faktor atau komponen utama dalam pertumbbuhan ekonomi dari setiap bangsa. Ketiganya adalah :

1. Akumulasi modal, meliputi semua bentuk atau jenis investasi baru yang ditanamkan pada tanah, peralatan fisik, dan modal atau sumber daya manusia

2. Pertumbuhan penduduk

3. Kemajuan teknologi

Menurut Sadono Sukirno (2006) terdapat empat factor yang menentukan pertumbuhan ekonomi, ke empat faktor tersebut adalah :

1. Tanah dan kekayaan alam lainnya

2. Jumlah dan mutu dari penduduk dan tenaga kerja

3. Barang-barang modal dan tingkat teknologi

4. Sistem sosial dan sikap masyarakat

\section{Hubungan Antara Pertumbuhan Ekonomi Terhadap Kemiskinan}

Menurut Tambunan (2001) menyatakan bahwa pertumbuhan ekonomi tanpa dibarengi dengan penambahan kesempatan kerja akan mengakibatkan ketimpangan dalam pembagian dari penambahan pendapatan tersebut (ceteris paribus), yang selanjutnya akan menciptakan suatu kondisi pertumbuhan ekonomi dengan peningkatan kemiskinan.

Pertumbuhan dan kemiskinan mempunyai korelasi yang sangat kuat, karena pada tahap awal proses pembangunan tingkat kemiskinan cenderung meningkat dan pada saat mendekati tahap akhir pembangunan jumlah orang miskinn berangsur-anggsur berkurang (Tmabunan, 2011). 


\section{Kerangka Konseptual Dan Hipotesis}

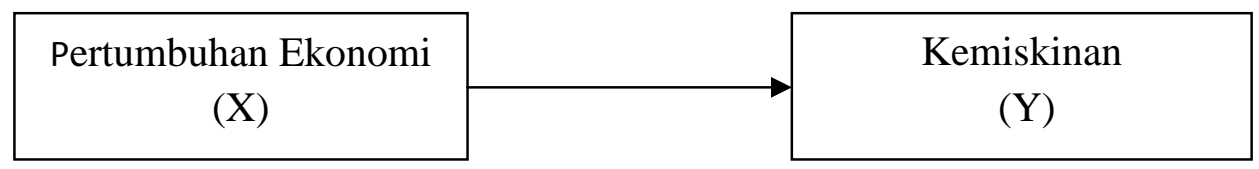

Gambar 1

\section{Kerangka Konseptual}

Berdasarkan permasalahan di atas, hipotesisnya adalah pertumbuhan ekonomi berpengaruh terhadap tingkat kemiskinan di Sumatera Utara.

\section{METODE PENELITIAN}

Teknik analisis data yang digunakan adalah analisis kuantitatif yaitu metode yang digunakan untuk menganalisis data yang berhubungan dengan masalah pengaruh pertumbuhan ekonomi terhadap tingkat kemiskinan di Sumatera Utara.

Dimana :

$$
\mathrm{Y}=\mathrm{a}+\mathrm{bX}+\mu
$$

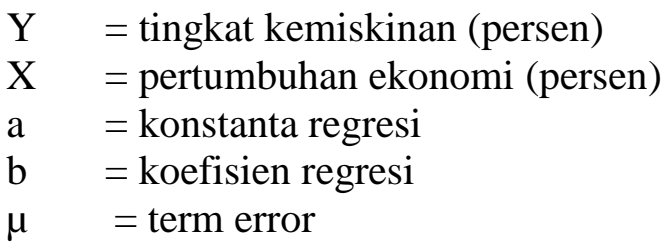

\section{PEMBAHASAN}

Dependent Variable: PERSENTASE_PENDUDUK_MISK

Method: Least Squares

Date: 08/10/16 Time: 11:52

Sample: 19962015

Included observations: 20

\begin{tabular}{lcccr}
\hline \hline \multicolumn{1}{c}{ Variable } & Coefficient & Std. Error & t-Statistic & Prob. \\
\hline \hline \multicolumn{1}{c}{ C } & 19.04905 & 0.713670 & 26.69169 & 0.0000 \\
PERTUMBUHAN_EKONOMI_X & -1.064604 & 0.116859 & -9.110187 & 0.0000 \\
\multicolumn{1}{c}{ R-squared } & 0.821774 & Mean dependent var & 13.98100 \\
Adjusted R-squared & 0.811873 & S.D. dependent var & 4.609350 \\
S.E. of regression & 1.999242 & Akaike info criterion & 4.318053 \\
Sum squared resid & 71.94546 & Schwarz criterion & 4.417626 \\
Log likelihood & -41.18053 & Hannan-Quinn criter. & 4.337491 \\
F-statistic & 82.99550 & Durbin-Watson stat & 0.507861 \\
Prob(F-statistic) & 0.000000 & & \\
\hline \hline
\end{tabular}

Sumber : data diolah, tahun 2016.

Setelah diregresikan data yang telah diperoleh maka persamaan regresi berikut dan kemudian akan dianalisis dengan menggunakan hasil regresi berikut ini :

$$
Y=19,04905-1,064604 X+\mu
$$


Berdasarkan hasil model estimasi dapat diinterpretasikan sebagai berikut : bahwa tingkat pertumbuhan ekonomi (X) mempunyai pengaruh negatif terhadap tingkat kemiskinan di propinsi Sumatera Uatara dengan besar koefisien 1,064604. Artinya apabila pertumbuhan ekonomi naik sebesar $1 \%$ maka tingkat kemiskinan di propinsi Sumatera Utara turun sebesar 1,064604\%.

\section{Uji R $\mathbf{R}^{2}$ ( Uji Koefisien Determinasi)}

Dari hasil regresi hubungan tingkat pertumbuhan ekonomi terhadap tingkat kemiskinan tahun1996-2015 diperoleh nilai $\mathrm{R}^{2}$ sebesar 0.821774 . Artinya $82,1774 \%$ variasi tingkat kemiskinan di Sumatera Utara dapat dijelaskan oleh variasi independennya yaitu tingkat pertumbuhan ekonnomi, sedangkan sisanya sebesar $17,8226 \%$ dijelaskan oleh variabel lain diluar model ini.

\section{Uji t (Uji Parsial)}

Uji t merupakan pengujian secara individual untuk membuktikan bahwa koefisien regresi ini secara statistik signifikan.

$\mathrm{H}_{0}: \beta 1=0$ (tidak ada pengaruh pertumbuhan ekonomi)

$\mathrm{H}_{1}: \beta 2 \neq 0$ (ada pengaruh pertumbuhan ekonomi)

Kriteria penerimaan atau penolakan sebagai berikut :

Tolak $\mathrm{H}_{0}$ jika nilai probabilitas $\mathrm{t}<$ dari taraf signifikan sebesar $0,05(\operatorname{sig}<\alpha 0,05)$

Terima $\mathrm{H}_{0}$ jika nilai probabilitas $\mathrm{t}>$ dari taraf signifikan sebesar $0,05(\operatorname{sig}>\alpha 0,05)$

Dari hasil pengolahan data diperoleh bahwa nilai probabilitas (sig) adalah 0,0000 ( $\operatorname{sig} 0,0000<\alpha 0,05$ ) dengan demikian $\mathrm{H}_{0}$ diditolak yang artinya pertumbuhan ekonomi berpengaruh dan signifikan terhadap tingkat kemiskinan.

\section{E. KESIMPULAN}

Pertumbuhan ekonomi mempunyai pengaruh yang negatif dan signifikan terhadap tingkat kemiskinan di propinsi Sumatera Utara.

\section{DAFTAR PUSTAKA}

Bachtiar Chamsyah, 2006, Teologi Penanggulangan Kemiskinan, RM-Books, Jakarta. Badan Pusat Statistik, Sumatera Utara dalam Angka Berbagai Thaun terbitan, BPS Propinsi Sumatera Utara.

BPS, 2009. "Jumlah dan Persentase Penduduk Miskinn, Garis Kemiskinan, Indeks Kedalaman Kemiskinan (P1) dan Indeks Keparahan Kemiskinan (P2) Menurut Propinsi, Maret 2009”, http://www.bps.go.id. Diakses 4 Desember 2014.

Jhingan, M.L, 2010, Ekonomi Pembangunan dan Perencanaan, PT. Raja Grafindo Persada, Jakarta.

Ravi Dwi Wijayanto, 2010, Analisis Pengaruh PDRB, Pendidikan dan Pengangguran Terhadap Kemiskinan di Kabupaten/Kota di Jawa Tengah Tahun 2005-2008, Skripsi S1, Faultas Ekonomi Universitas Diponegoro, Semarang.

Sadono Sukirno, 2000, Makro Ekonomi Modern, PT. Raja Grafindo Persada, Jakarta.

Sumedi dan Supardi, 2004, "Keiskinan di Indonesia : Suatu Fenomena Ekonomi" Icaserd Working Paper No.21, PUsat Penelitian Pengembangan Sosial Ekonomi Pertanian, Departemen Pertanian, Agustus 2011, Bogor.

Tambunan, Tulus T.H, 2001, Perekonomian Indonesia, Ghalia Indonesia, Jakarta.

Tambunan, Tulus, T.H, 2011, Perekonomian Indonesia, Kajian Teoritis dan Analisis Empiris, Ghalia Indonesia, Jakarta. 
Todaro, M.P, 1997, "Pembangunan Ekonomi di Dunia Ketiga",Edisi VI, Erlangga, Jakarta.

Todaro, M.P, 2000, "Pembangunan Ekonomi di Dunia Ketiga", Edisi VII, Erlangga, Jakarta. 